\title{
Pineus boerneri Annand, 1928 (Hemiptera, Adelgidae) - a new species to Brazil: morphology of eggs, nymphs and adults
}

\author{
Sonia Maria Noemberg Lazzari ${ }^{1} \& J_{0}$ Jiane Teresinha Cardoso²
}

\begin{abstract}
'Departamento de Zoologia, Universidade Federal do Paraná, Caixa Postal 19020, 81531-980 Curitiba-PR, Brasil. lazzari@ufpr.br ${ }^{2}$ Departamento de Engenharia Ambiental, Universidade do Estado de Santa Catarina, Av. Luiz de Camões, 2090, 88520-000 Lages-SC. jositc@yahoo.com.br
\end{abstract}

\begin{abstract}
Pineus boerneri Annand, 1928 (Hemiptera, Adelgidae) - a new species to Brazil: morphology of eggs, nymphs and adults. Pineus boerneri represents the first Adelgidae species recorded in Brazil. This aphid species forms extensive colonies on branches and trunk of Pinus spp., with apterous oviparous females, eggs and nymphs covered with white wax. The aim of this research is to study the morphology of eggs, nymphs, and adults to provide useful data for species identification in order to solve taxonomic issues. The study was based on morphometric data and optical and scanning electron microscopy images. First instar nymphs are active and can be easily distinguished from the others by their elongate minute yellowish body; well developed legs bearing a pair of sensorial setae at the apex of the second tarsomere; and antenna with three segments with a large rhinarium and distinct apical setae on the last segment. From the second to the fourth instar, nymphs are sessile, with round red body; they loose the third antennal segment and its sensorial structures, as well as the setae on the second tarsomere. The oviparous female is reddish-brown, with round body with about $0.76 \mathrm{~mm}$ diameter; legs reduced; antennae one-segmented; ovipositor distinct; numerous wax glands are present, mainly on the head. Accurate characterization of the species and distinction of the nymphal instars of $P$. boerneri were made possible by canonical analysis of morphometric data and morphological characters.
\end{abstract}

KEYWORDS. Morphometrics; pine woolly aphid; Pinus; scanning microscopy.

RESUMO. Pineus boerneri Annand, 1928 (Hemiptera, Adelgidae) - uma espécie nova para o Brasil: morfologia de ovos, ninfas e adultos. Pineus boerneri representa a primeira espécie de Adelgidae registrada no Brasil. Esta espécie de Adelgidae forma densas colônias em ramos e tronco de Pinus spp., com fêmeas ovíparas ápteras, ovos e ninfas recobertos por lanugem branca. A presente pesquisa teve como objetivo estudar a morfologia de ovos, ninfas e de fêmeas adultas, visando à identificação correta da espécie, para solucionar problemas taxonômicos. O estudo das formas baseou-se na morfometria e microscopia ótica e eletrônica de varredura. As ninfas de primeiro instar são ativas, de coloração amarelada, diferenciadas das demais pelo formato alongado do corpo; pernas bem desenvolvidas com um par de cerdas sensoriais no ápice do segundo segmento tarsal; antenas com três segmentos, com um rinário e cerdas apicais bem distintas. A partir do segundo instar, as ninfas são sésseis, apresentam corpo arredondado de coloração avermelhada, perdem o terceiro segmento antenal e as cerdas e estruturas sensoriais do segundo segmento tarsal. As fêmeas adultas são marromavermelhadas, apresentam corpo arredondado, com aproximadamente $0,76 \mathrm{~mm}$ de diâmetro; pernas reduzidas; um único segmento antenal bem reduzido; ovipositor distinto; e numerosas glândulas de cera, principalmente, na região da cabeça. A caracterização da espécie e distinção dos ínstares é possível pela análise canônica dos dados morfométricos e caracteres morfológicos.

PALAVRAS-CHAVE. Morfometria; microscopia eletrônica de varredura; pulgão-lanígero-do-pinus; Pinus.

Pineus Shimer, 1869 (Hemiptera, Adelgidae) comprises about 29 species, feeding exclusively on Pinaceae of the genera Picea A. Dietr. and Pinus L., except for Pineus abietinus Underwood and Balch, which feeds on Abies Mill. in North America (Blackman \& Eastop 1994). Most species are holocyclic, alternating between Picea as primary host and Pinus as secondary host. Anholocyclic species colonize mainly Pinus (Eastop 1966; Blackman \& Eastop 1994; Havill \& Foottit 2007). According to Havill \& Foottit (2007), species of Adelgidae show, in general, reduction of morphological characters, such as antennal segments and legs. Interspecific variation of adults makes the identification of the species a difficult task.

The pine wooly aphid, Pineus boerneri Annand, 1928, represents the first record of an Adelgidae species in Brazil (Iede et al. 2007). This species was firstly detected in the Southern Region in 2000, and was rapidly dispersed through- out the South and Southeast regions. It was observed on Pinus taeda L., Pinus elliottii Engelmann, and Pinus caribaea Morelet (Susete Penteado; Carlos Wilcken - personal communication). Adult females of $P$. boerneri are sessile, small reddish-brown round insects (approximately $0.76 \mathrm{~mm}$ in diameter), with wax glands on the head and thorax; males have not been described (Yassen \& Ghani 1971; Zondag 1977; Blackman \& Eastop 1994).

Pineus boerneri was early described infesting Pinus radiata D. Don, in California, but it probably has its origin in East Asia, the native range of its host plant, Pinus thumbergiana Franco (McClure 1990). Because its taxonomy is not well established, it has been described under different names in several parts of the world.

Pineus laevis (Maskell, 1885) Börner, 1907 was described by Maskel in 1885 (McClure 1982) infesting three exotic species of Pinus in New Zealand. Eastop (1966) and McClure 
(1982) suggested that this species might possibly be $P$. boerneri. Eastop (1966) mentions two species of Pineus in Australia: Pineus pini Gmelin, 1790 on Pinus sylvestris L. and $\mathrm{P}$. laevis on $P$. radiate. These species are not easily distinguished and perhaps both might be $P$. boerneri. Tanton \& Alder (1977) treat $P$. boerneri as $P$. laevis, forming the complex laevis/pini. McClure (1982) emphasizes the need of studying the type material of both $P$. laevis and $P$. boerneri in order to confirm their taxonomic status. Blackman \& Eastop (1994), however, treat $P$. laevis as synonym of $P$. pini. According to the authors, the species described by Maskel, 1895 could be $P$. pini, which might occur simultaneously with $P$. boerneri in Australia and New Zealand, and have been confused due to their morphological similarity. The two species are also confused in Africa (Blackman \& Eastop 1994), and probably the papers published on $P$. pini may refer to $P$. boerneri or both species.

According to Blackman \& Eastop (1994), P. boerneri was described in Argentina as Pineus havrylenkoi (Blanchard 1944), where apterous parthenogenetic females and winged sexuparae were observed on P. sylvestris. In Zimbabwe (= Rhodesia), Barnes et al. (1976) treated P. havrylenkoi as being, possibly, P. pini. According to Blackman \& Eastop (1994), P. boerneri was described by Yassen \& Ghani (1971) under the name Pineus simmondsi Yassen \& Ghani, 1971, based on apterous parthenogenetic females occurring on Pinus roxburghii Sargent, in Pakistan.

The pine wooly aphid is distributed in North America, Europe, New Zealand, Australia, Chile, South Africa, Malaysia, Taiwan, Kenya, Malawi, and Pakistan (Blackman \& Eastop 1994), infesting over 40 species of Pinus. In some areas of New England (USA), P. boerneri is a serious pest of red pine, Pinus resinosa Aiton, where it injures and kills trees at all of the inhabited sites. It is parthenogenetic, trivoltine, and the life stages are readily distinguished from one another by body size and by several morphological features including antennae, setae, and wax-producing glands. $P$. boerneri displaced Pineus coloradensis (Gillette) in cohabited pine stands where the later species initially had occurred alone and was reduced to very low density (McClure 1989). In Brazil, there are no studies on economic impact of $P$. boerneri on Pinus plantations.

$P$. boerneri is exclusively oviparous; the female is apterous and sessile, and covers the eggs with wax threads secreted by the head and thoracic glands (McClure 1989; Blackman \& Eastop 1994). McClure (1989) observed four nymphal instars for this species in the United States; while Yassen \& Ghani (1971) found only three instars in Pakistan. The first instar nymphs are crawlers responsible for the dispersion on the plant and for choosing feeding sites; the other instars are sessile (Blackman \& Eastop 1994; McClure 1989).

Since $P$. boerneri has been recently introduced in Brazil and is the only species of Adelgidae recorded here, this study aims to describe detailed morphology of all stages to facilitate the correct identification of $P$. boerneri to solve taxonomic problems.

\section{MATERIAL AND METHODS}

The insects used for the morphometric analysis were collected in Adrianópolis, Paraná State, on a plantation of P. taeda, in July 2006. The eggs were obtained from a laboratory stock colony on P. taeda and P. elliottii. Nymphal instars were identified based on the number of exuviae left near the newly molted insects. Only adult females bearing eggs were measured; crawling nymphs were considered to be of first instar.

Individuals were removed from the plants and preserved in $70 \%$ ethanol. The specimens were placed in an excavated porcelain plate with lactic acid for about 24 hours; after clarification, they were placed on a clean slide on a drop of lactic acid and covered with the cover slip supported on small pieces of glass to avoid flattening.

The length and width of 30 eggs were measured. For nymphs, a total of $11,17,16$, and 20 specimens, of the first, second, third, and fourth instars, respectively, were measured. The following characters were measured: body length and width; length and width of antennal segments I, II and III; length of apical setae of the antenna; length and width of femur, tibia, and second tarsal segment of hind leg; length of seta on the hind second tarsal segment of hind leg; length and width of rostral segments III and IV $+V$. Sixteen specimens of adult oviparous females were measured: body length and width; length and width of antennal segment I; femur, tibia, and second tarsal segment of hind leg; rostral segments III and IV+V; length of anal plate and ovipositor.

The specimens were photographed using a Window Canon Power Shot A620 and measurements were obtained using AxioVision 4.5 software (Zeiss). Means were compared by the Tukey test at 5\% probability. Morphometric data of second, third and fourth instars were submitted to variance analysis using Statistica 5.5 and canonical analysis using groups of 10 to 16 individuals, based on 16 variables common to all instars, transformed into log 10. The Kappa index was calculated to check the accuracy of the results. It was applied in order to evaluate the agreement between measurements because it is more precise in relation to variation caused by error of either omission or inclusion (Cohen 1960). The advantage of using this method is that all elements of the error matrix are considered, not only those of the main diagonal (Moreira 2001). The Kappa index " 0 " indicates that there is no concordance between measurements, whereas " 1 " indicates full agreement. These analyses were run using the software JPM 3.2.2. Permanent slides were deposited in the Coleção Entomológica Pe. Jesus Santiago Moure, Departamento de Zoologia, Universidade Federal do Paraná (DZUP).

For scanning electron microscopy (SEM), a few eggs, first instar nymphs and adult females were selected from the stock colony, cleaned with a fine paintbrush to remove the wax. The specimens were glued directly on stubs with double-sided tape, metalized with gold (SCD030, Balzers Union, FL 9496), and analyzed under a scanning electron microscope (Philips, series XL 30 with dispersive energy of X-ray-X model EDAX and DX-4i). 


\section{RESULTS}

Characterization of $\boldsymbol{P}$ boerneri colonies. Colonies are composed of adult females on top of numerous eggs and surrounded by nymphs forming continuous colonies all over the branch, especially near crevices on the bark. The colony is covered with white woolly wax produced by nymphs and adults (Figs. 1-4). In young colonies, the wax is white, but turns yellow when colonies age, covering dead insects and exuviae. First instar nymphs start to secret wax as soon as they settle down on the feeding site. Exuviae remain near the insects, stuck with wax threads.

Infestation starts with single females establishing on the branches or trunk of pine trees. First instar nymphs or crawlers usually search for feeding sites away from their mothers, but as the population increases they settle down around older females.

Egg morphology. Elliptical, without ornamentations, yellow when newly laid (Figs. 2, 3, 20), becoming orange before hatching. Mean length and width are, respectively, $338.2 \mu \mathrm{m}$ (299.7-388.7) and 173.0 $\mu \mathrm{m}$ (137.2-239.8).

Nymph morphology. Newly emerged nymphs are yellow (Fig. 4), darkening at each molt until the fourth instar when they turn dark-red. Wax glands are present on the head (Figs. 15, 16).
First instar nymphs are elliptical (Figs. 9, 13, 14), with body length/width ratio of 1.79 . Subsequent instar nymphs become more rounded, with length/width ratio decreasing gradually from 1.42 (second) to 1.36 (third) to 1.34 (fourth). Body measurements were significantly different from one instar to the next, except for second and third instars, which were very similar (Table I).

First instar nymph bears 3-segmented antennae with a rhinarium on the third segment and a pair of short setae and one long seta (average of $34.1 \mu \mathrm{m}$ long) in the apex (Figs. 10, $11,19)$. The length and width of the third antennal segment were, respectively, $60.5 \mu \mathrm{m}$ and $15.5 \mu \mathrm{m}$. In the second instar nymphs loose the third antennal segment and segment I is shorter and narrower than it was in the previous instar (Table I).

Antennal segment II and hind legs decrease in size from one instar to the next (Table I). First instar nymphs have a pair of apical setae on the second tarsal segment, about 25.6 $\mu \mathrm{m}$ long (Figs. 12, 18), which disappears after the next molt.

There was no variation in length of rostral segments III and IV+V amongst instars, except for a longer segment IV $+\mathrm{V}$ in the first instar (Fig. 17). The width of these two segments, however, increases from one instar to the next, evidenced by the ratio between the length and width of segment III: 0.82 , $0.70,0.67$, and 0.65 ; and of segments IV+V: $1.57,1.26,1.13$, and 1.09; for respective instars.
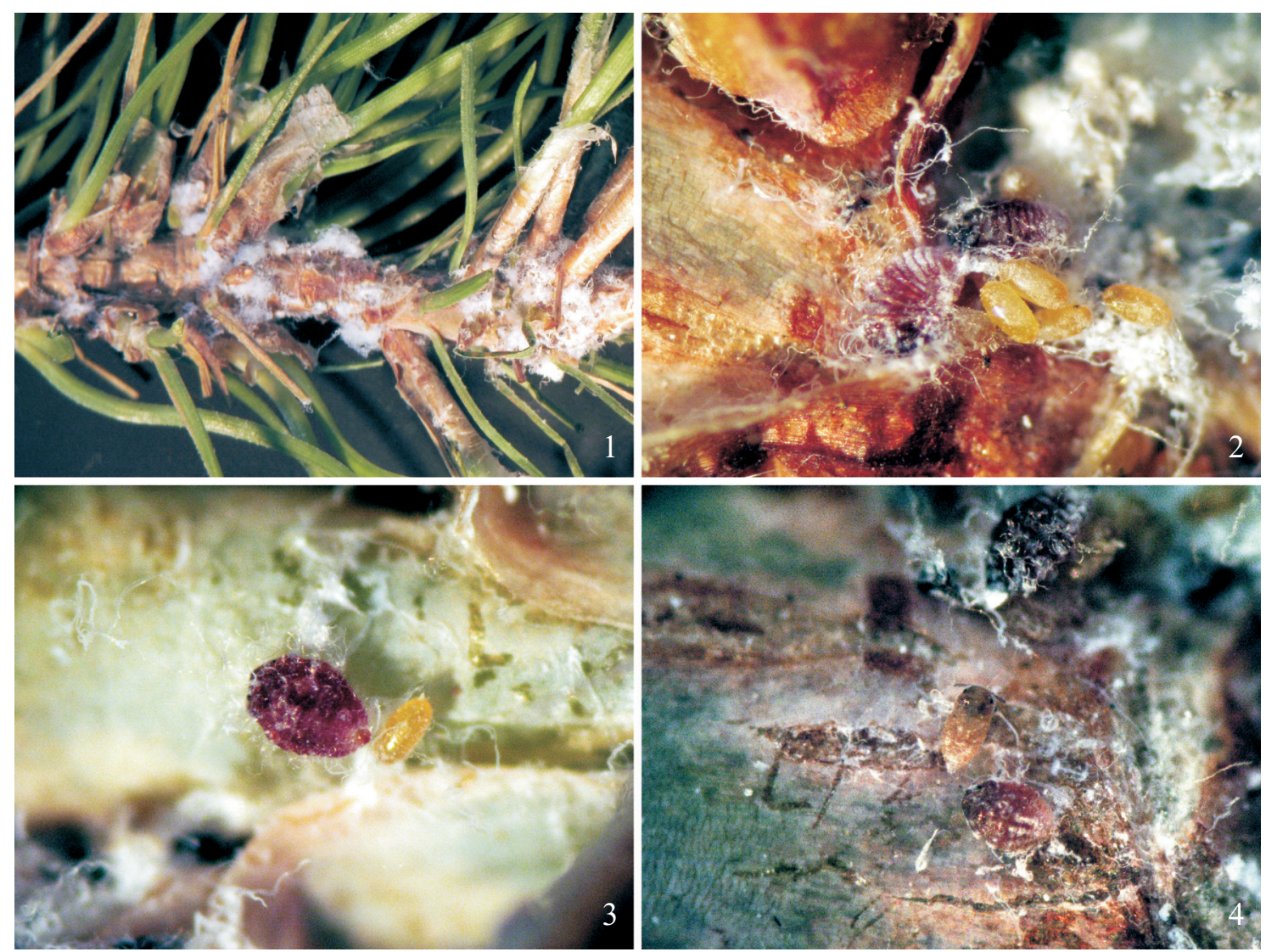

Figs. 1-4. One year old Pinus taeda seedling bearing colonies of Pineus boerneri. 1, white woolly wax secreted by adults and nymphs; 2 . apterous adult female and eggs covered with wax; 3 , apterous adult female and egg; 4 . nymphs. 

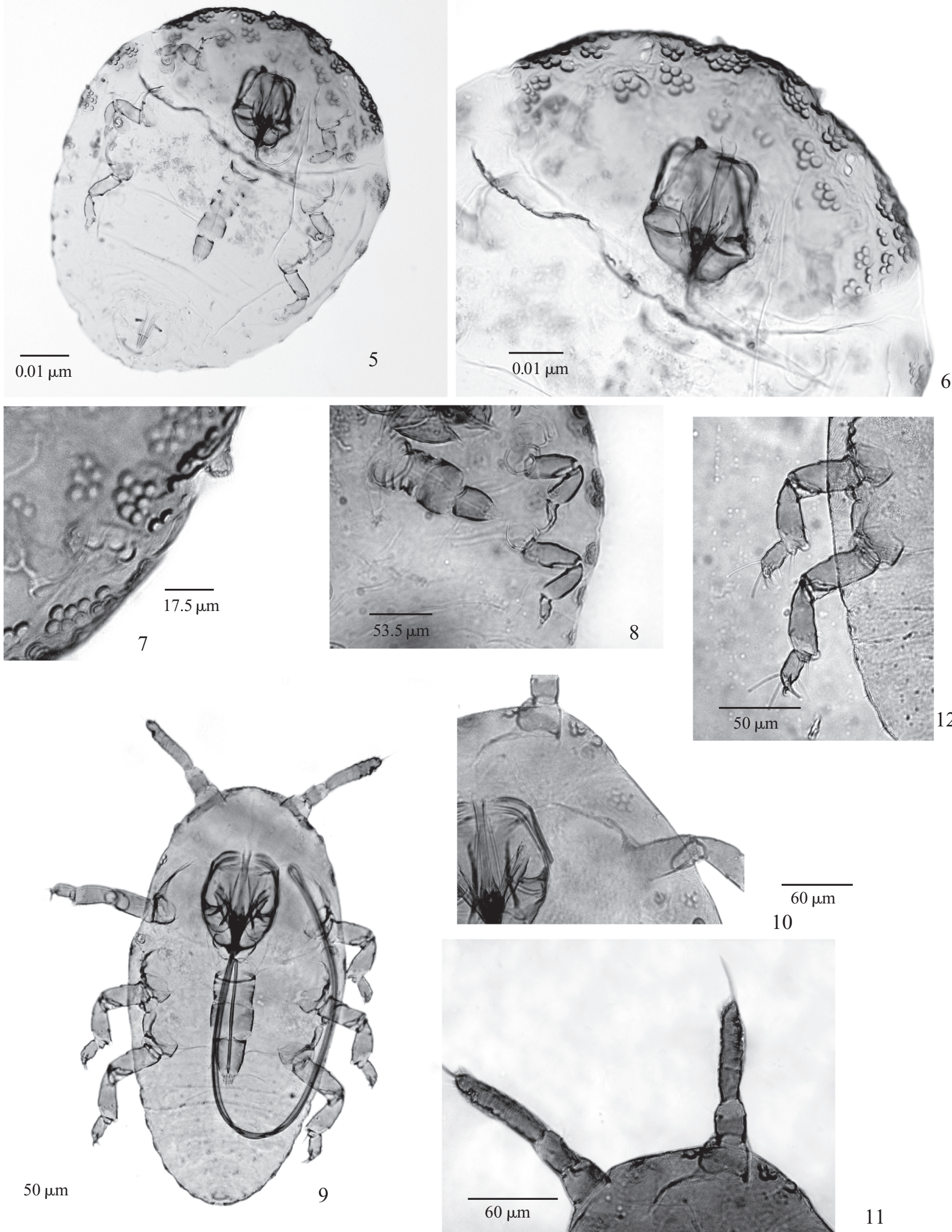

Figs. 5-12. Pineus boerneri: 5-8. apterous adult female: 5, ventral view; 6, head; 7, antenna; 8, middle and hind legs. 9-12. $1^{\text {st }}$ instar nymph: 9, ventral view of body and rostrum with stylets; 10 , head; 11, antenna; 12 , middle and hind legs. 

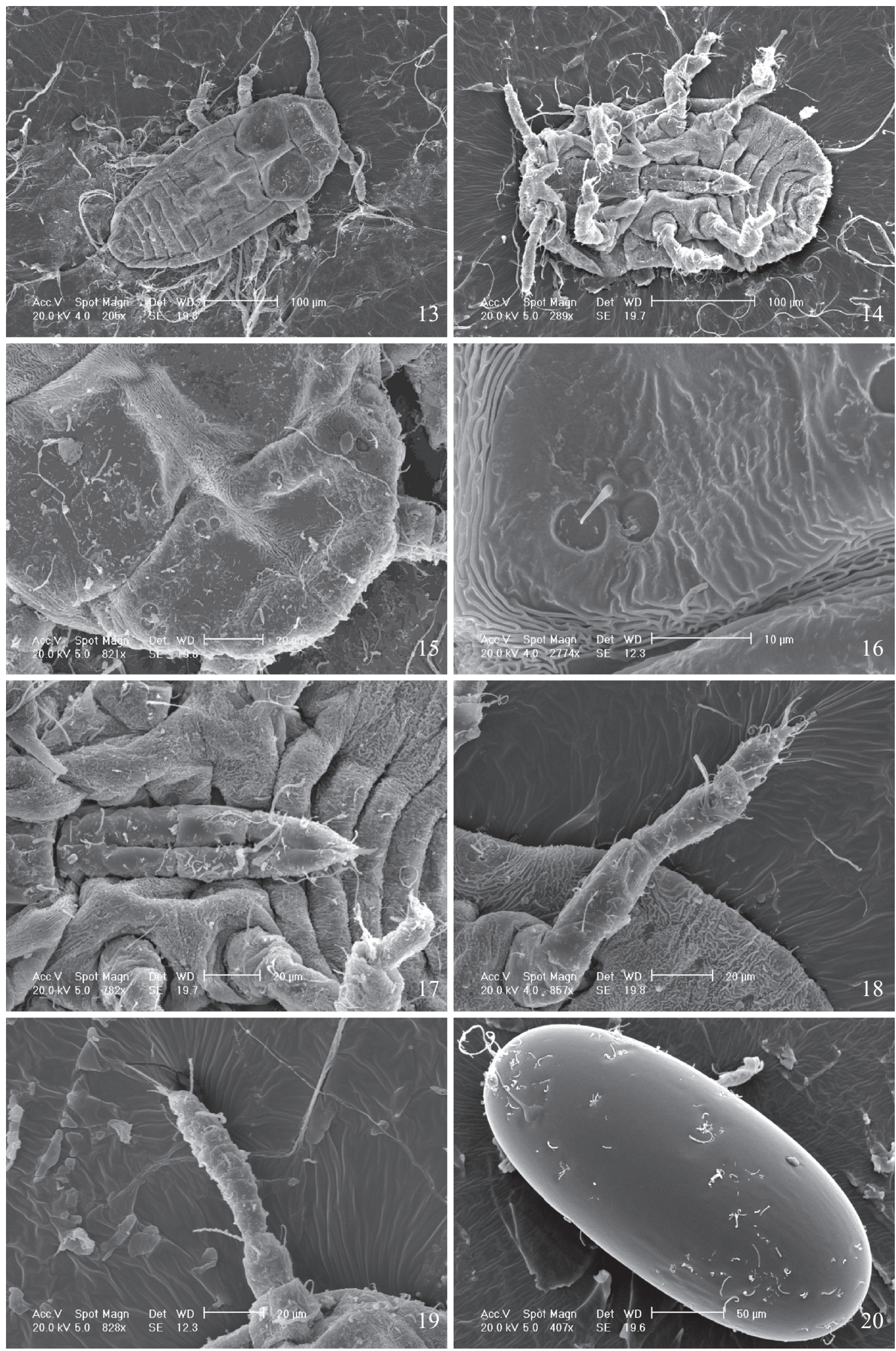

Figs. 13-20. Electronic scanning microscopy of Pineus boerneri: 13-19. $1^{\text {st }}$ instar nymph: 13 dorsal view; 14, ventral view; 15, head; 16, wax glands; 17 , rostrum; 18, hind leg; 19, antenna. 20. egg. 

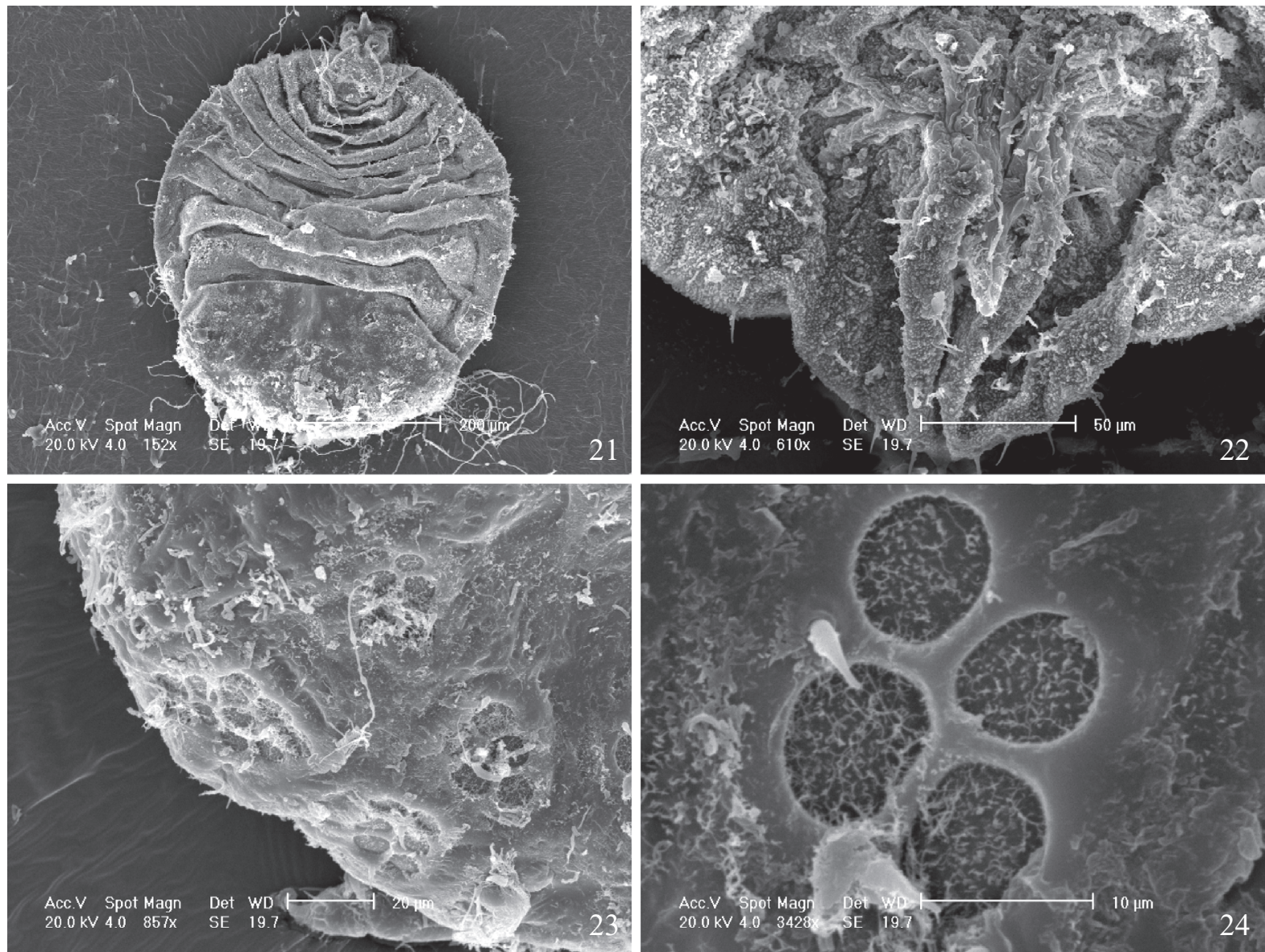

Figs. 21-24. Electronic scanning microscopy of apterous oviparous female of Pineus boerneri: 21, dorsal view; 22, ovipositor; 23, wax glands; 24, details of a wax gland.

Table I. Morphological characters (mean \pm standard error) of nymphal instars and of apterous oviparous females of Pineus boerneri collected on Pinus spp. in Paraná, Brazil.

\begin{tabular}{lccccc}
\hline \multicolumn{1}{c}{ Characters $(\mathrm{mm})$} & Instar I $(\mathrm{n}=11)$ & Instar II $(\mathrm{n}=17)$ & Instar III $(\mathrm{n}=16)$ & Instar IV $(\mathrm{n}=20)$ & Adult female $(\mathrm{n}=16)$ \\
\hline Body length & $0.3910 .78 \mathrm{c}$ & $0.519 \pm 0.10 \mathrm{~b}$ & $0.533 \pm 0.10 \mathrm{~b}$ & $0.597 \pm 0.65 \mathrm{a}$ & $0.672 \pm 0.17$ \\
Body width & $0.220 \pm 0.6 \mathrm{c}$ & $0.368 \pm 0.11 \mathrm{~b}$ & $0.394 \pm 0.83 \mathrm{~b}$ & $0.445 \pm 0.55 \mathrm{a}$ & $0.535 \pm 0.10$ \\
Length of antennal segment I & $0.22 \pm 0.06 \mathrm{a}$ & $0.16 \pm 0.08 \mathrm{~b}$ & $0.11 \pm 0.05 \mathrm{c}$ & $0.94 \pm 0.03 \mathrm{~d}$ & $0.17 \pm 0.05$ \\
Width of antennal segment I & $0.24 \pm 0.06 \mathrm{a}$ & $0.21 \pm 0.07 \mathrm{~b}$ & $0.17 \pm 0.05 \mathrm{c}$ & $0.17 \pm 0.06 \mathrm{c}$ & $0.18 \pm 0.1$ \\
Length of antennal segment II & $0.24 \pm 0.09 \mathrm{a}$ & $0.20 \pm 0.11 \mathrm{~b}$ & $0.12 \pm 0.06 \mathrm{c}$ & $0.11 \pm 0.07 \mathrm{c}$ & - \\
Width of antennal segment II & $0.18 \pm 0.05 \mathrm{a}$ & $0.17 \pm 0.06 \mathrm{ab}$ & $0.15 \pm 0.06 \mathrm{~b}$ & $0.15 \pm 0.06 \mathrm{~b}$ & - \\
Length of femur III & $0.50 \pm 0.09 \mathrm{a}$ & $0.49 \pm 0.07 \mathrm{a}$ & $0.46 \pm 0.09 \mathrm{~b}$ & $0.46 \pm 0.07 \mathrm{~b}$ & $0.53 \pm 0.09$ \\
Width of femur III & $0.22 \pm 0.05 \mathrm{~b}$ & $0.27 \pm 0.08 \mathrm{a}$ & $0.27 \pm 0.10 \mathrm{a}$ & $0.25 \pm 0.05 \mathrm{ab}$ & $0.28 \pm 0.09$ \\
Length of tibia III & $0.48 \pm 0.12 \mathrm{a}$ & $0.41 \pm 0.12 \mathrm{~b}$ & $0.38 \pm 0.17 \mathrm{~b}$ & $0.40 \pm 0.08 \mathrm{~b}$ & $0.47 \pm 0.1$ \\
Width of tibia III & $0.23 \pm 0.11 \mathrm{ab}$ & $0.23 \pm 0.12 \mathrm{a}$ & $0.20 \pm 0.03 \mathrm{~b}$ & $0.22 \pm 0.06 \mathrm{ab}$ & $0.24 \pm 0.1$ \\
Length of 2nd tarsal segment III & $0.23 \pm 0.06 \mathrm{a}$ & $0.19 \pm 0.06 \mathrm{~b}$ & $0.16 \pm 0.07 \mathrm{c}$ & $0.16 \pm 0.05 \mathrm{c}$ & $0.18 \pm 0.08$ \\
Width of 2nd tarsal segment III & $0.13 \pm 0.03 \mathrm{a}$ & $0.12 \pm 0.04 \mathrm{ab}$ & $0.11 \pm 0.04 \mathrm{c}$ & $0.11 \pm 0.03 \mathrm{bc}$ & $0.12 \pm 0.03$ \\
Length of rostral segment III & $0.33 \pm 0.07 \mathrm{a}$ & $0.33 \pm 0.05 \mathrm{a}$ & $0.34 \pm 0.07 \mathrm{a}$ & $0.34 \pm 0.05 \mathrm{a}$ & $0.39 \pm 0.07$ \\
Width of rostral segment III & $0.40 \pm 0.06 \mathrm{c}$ & $0.47 \pm 0.11 \mathrm{c}$ & $0.50 \pm 0.06 \mathrm{~b}$ & $0.53 \pm 0.05 \mathrm{a}$ & $0.51 \pm 0.1$ \\
Length of rostral segment IV+V & $0.46 \pm 0.09 \mathrm{a}$ & $0.40 \pm 0.05 \mathrm{~b}$ & $0.38 \pm 0.07 \mathrm{~b}$ & $0.39 \pm 0.04 \mathrm{~b}$ & $0.42 \pm 0.07$ \\
Width of rostral segment IV+V & $0.30 \pm 0.08 \mathrm{c}$ & $0.32 \pm 0.08 \mathrm{bc}$ & $0.33 \pm 0.06 \mathrm{ab}$ & $0.35 \pm 0.04 \mathrm{a}$ & $0.35 \pm 0.07$ \\
Length of anal plate & - & - & - & - & - \\
Length of ovipositor & - & - & - & $0.35 \pm 0.1$ & $0.63 \pm 0.1$ \\
\hline
\end{tabular}

Different letters indicate significant statistical differences in the lines by the Tukey test $(\mathrm{p}<0,05 \%)$. 
Variance analysis showed significant differences for body length and width of antennal segments I and II, length of hind femur and second tarsal segment, width of hind femur and rostral segments II and III amongst third and fourth instars. However, the Tukey test (Table I) found significant difference among the three instars only in the length of antennal segment I and width of rostral segment III. The width of antennal segment I and length of antennal segment II, hind femur, and second tarsal segment were useful for distinguishing the second instar from others. Body length and width of fourth instar nymphs were significantly different. For most characters, however, measurements overlap and do not readily discriminate the instars of $P$. boerneri.

Five groups were used for canonical analysis, accounting for $87.2 \%$ of the variability amongst instars. The main components in each group were: body length and width and the length of antennal segments I and II, structures that showed significant differences by variance analysis. Canonical analysis distinguished four out of the five groups: (1) all first instar; (2) 94\% of second instar; (3) 94\% of third instar; and (4) $93 \%$ of fourth instar nymphs (Table II). The Kappa index

Table II. Percent of correct grouping of individual specimens of nymphs of Pineus boerneri reared on Pinus spp. in Paraná, Brazil, based on morphometric characters by canonical analysis.

\begin{tabular}{lcccc}
\hline & $\begin{array}{c}1^{\text {st }} \text { instar } \\
(\mathrm{N}=10)\end{array}$ & $\begin{array}{c}2^{\text {nd }} \text { instar } \\
(\mathrm{N}=16)\end{array}$ & $\begin{array}{c}3^{\text {rd }} \text { instar } \\
(\mathrm{N}=16)\end{array}$ & $\begin{array}{c}4^{\text {th }} \text { instar } \\
(\mathrm{N}=15)\end{array}$ \\
\hline Group 1 & $10(100 \%)$ & 0 & 0 & 0 \\
Group 2 & 0 & $15(94 \%)$ & 0 & 0 \\
Group 3 & 0 & $1(6 \%)$ & $15(94 \%)$ & $1(7 \%)$ \\
Group 4 & 0 & 0 & $1(6 \%)$ & $14(93 \%)$ \\
Kappa index & 0.929 & & & \\
\hline
\end{tabular}

of 0.93 confirms the high accuracy of the data analyzed.

Canonical variables 1 and 2 were responsible for the largest variability (Fig. 25), placing the four instars in distinct groups. Nymphs of the second, third, and fourth instars collected from large continuous colonies could not be separated, but could be distinguished by multivariate analysis. The distinction, however, is not clear using the analysis of comparison of means.

Adult morphology. Apterous parthenogenetic oviparous females are the only adult morphs recorded in Brazil. They are sessile, round, dark-red morphs (Figs. 2, 3, 5, 21), cauda and siphunculi absent, bearing ovipositor. The Tukey test showed significant differences between body length and width of adult females and fourth instar nymphs, ranging from 0.55 to $0.82 \mathrm{~mm}$ and from 0.47 to $0.62 \mathrm{~mm}$, respectively. In addition to the larger size, adults differ from nymphs because they bear a single antennal segment (Fig. 7) and distinct ovipositor (Fig. 22). Adults of $P$. boerneri have groups of wax glands, mostly on the head (Figs. 6, 23, 24) and fewer on the thorax and abdomen. There are groups of 2 to 10 wax gland openings between the eyes.

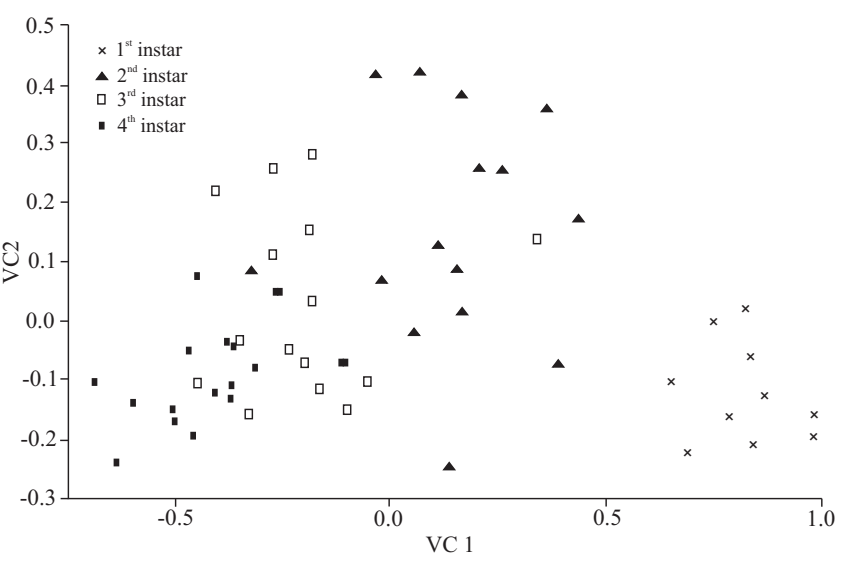

Fig. 25. First (VC1) and second (VC2) canonical variables of morphometric characters of nymphs of Pineus boerneri collected on Pinus spp. in Paraná, Brazil.

\section{DISCUSSION}

Morphometric measurements obtained for eggs of $P$. boerneri were in average larger than values obtained by McClure (1989) for populations on P. resinosa from the United States ( 250 to $320 \mu \mathrm{m}$ in length and 150 to $200 \mu \mathrm{m}$ in width).

As observed in this study for $P$. boerneri and according to Havill \& Foottit (2007), first instar nymphs of Adelgidae have longer legs and antennae when compared to later instars, which help them to locate feeding sites on the host plant. In addition, the presence of apical sensorial setae and rhinaria on the antennae and sensorial setae on the legs of first instar nymphs are related to dispersion and feeding site location when establishing new colonies. These structures are lost in later instars because nymphs become sessile. First instar nymphs of $P$. boerneri can be distinguished from nymphs of other instars by several morphological characters, whereas distinction of subsequent instars can be made only by canonical analysis of a set of characters.

The Tukey test at $5 \%$ probability showed significant differences for mean body length and width between fourth instar nymphs $(0.60 \mathrm{~mm}$ and $0.45 \mathrm{~mm}$, respectively) and adult females ( $0.67 \mathrm{~mm}$ and $0.54 \mathrm{~mm}$, respectively) reared on P. taeda. McClure (1989) obtained seasonal differences for body measurements for $P$. boerneri infesting $P$. resinosa in the United States. The fourth instar nymphs collected during spring-summer $(0.57 \mathrm{~mm}$ long and $0.46 \mathrm{~mm}$ wide) were about the same size as those observed in our study, but the winter morphs were much smaller ( $0.44 \mathrm{~mm}$ long and $0.36 \mathrm{~mm}$ wide). However, adult females were larger in the winter $(0.74 \mathrm{~mm}$ long and 0.60 wide) and even larger in spring-summer (0.94 mm long and $0.70 \mathrm{~mm}$ wide). In Pakistan (Yassen \& Ghani 1971), body size of first instar nymphs ( 0.40 to $0.45 \mathrm{~mm}$ in length and 0.23 to $0.27 \mathrm{~mm}$ in width) and adult females $(0.63$ to $0.67 \mathrm{~mm}$ in length and 0.61 to $0.67 \mathrm{~mm}$ in width) were similar to those found here. In Southern and Eastern Africa, Mills (1990) found quite large adult morphs of $P$. boerneri with approximately 1 mm body length. Although, body sizes are comparable between the populations studied in Brazil and Pakistan, first instar 
nymphs are light-brown and adults yellowish-brown in the latter (Yassen \& Ghani 1971), but darker in our specimens.

The oviparous female of $P$. boerneri bears only one antennal segment, confirmed by Yassen \& Ghani (1971) for this same species, in Pakistan. According to Blackman \& Eastop (1994), the parthenogenetic adult female of P. pini is also apterous, but differs from the oviparous female of $P$. boerneri because presents either two or three antennal segments. Groupings of wax glands, mainly on head, agree with descriptions by Blackman \& Eastop (1994), who also found these glands on two or more abdominal tergites. The presence of ovipositor and the absence of cauda, siphunculi, and antennal terminal process are considered primitive characters of Aphidoidea, indicating that $P$. boerneri and all other Adelgidae form a basal group within this super-family (Evans 1963; Heie 1987; Moran 1992).

Comparing morphological characters of $P$. boerneri with those of P. havrylenkoi from Argentina (Blanchard 1944), the first instar nymph of the later has a rhinarium at the middle and four rhinaria on the apex of the third antennal segment, whereas the former bears a rhinarium on the third segment and a pair of short setae and one long seta in the apex. The apterous female of $P$. havrylenkoi presents three antennal segments, whereas P. boerneri has only one. This author also describes the alate sexupara, which has not been recorded for $P$. boerneri in any part of the world. It is necessary to verify the type species of P. havrylenkoi, but the data we found strongly suggest that it is a distinct species, disagreeing with Blackman \& Eastop (1994) who considered $P$. havrylenkoi a synonymous of $P$. boerneri. However, it is possible that $P$. havrylenkoi is synonymous of $P$. pini because adult females of both present three antennal segments and sexual morphs. Thus, based on our morphological studies and data from the literature, we found out that the Adelgidae species recorded in Brazil is the same species described in the United States as Pineus boerneri Annand, 1928, as well as the same species described in Pakistan as Pineus simmondsi Yassen \& Ghani, 1971. On the other hand, it does not appear to be the same species described in Argentina as Pineus havrylenkoi Blanchard, 1944.

Identification of Adelgidae species is complex because of morphological similarities and intraspecific variation; also because the same species may colonize different host plants. Sessile habit of apterous females causes reduction of structures normally used as taxonomic characters make the identification also difficult. We concluded that the two Pineus species recorded in South America to date are P. havrylenkoi in Argentina and P. boerneri in Brazil and Chile; however, to solve the confusion between $P$. boerneri and $P$. pini requires intensive investigation of populations from different areas and molecular analysis to evaluate their variability.

\section{ACKNOWLEDGMENTS}

Contribution number 1825 of the Departamento de Zoologia, Universidade Federal do Paraná. To CNPq-Brazil for fellowships to the authors.

\section{REFERENCES}

Barnes, R. D.; R. F. Jarvis; M. A.Schweppenhauser \& L. J. Mullin. 1976. Introduction, spread and control of the pine woolly aphid, Pineus pini (L), in Rhodesia. South African Forestry Journal 96: 1-11.

Blackman, R. L. \& V. F. Eastop 1994. Aphids on the world's trees: an identification and information guide. Wallingford, CAB International, $987 \mathrm{p}$.

Blanchard, E. E. 1944. Descripciones y anotaciones de afidoideos argentinos. Acta Zoologica Lilloana 2: 15-62.

Cohen, J. 1960. A coefficient of agreement for nominal scales. Educational and Psychological Measurement 20: 37-46.

Eastop, V. F. 1966. A taxonomic study of Australian Aphidoidea (Homoptera). Australian Journal of Zoology 14: 399-592.

Evans, J. W. 1963. The phylogeny of the Homoptera. Annual Review of Entomology 8: $77-94$.

Havill, N. P. \& R. G. Foottit. 2007. Biology and Evolution of Adelgidae. Annual Review of Entomology 52: 325-349.

Heie, O. E. 1987. Paleontology and phylogeny, p. 367-391. In: A. K. Minks; P. Harrewijn (Eds.) Aphids. Their Biology, Natural Enemies and Control. Amsterdam, Elsevier, $450 \mathrm{p}$.

Iede, E. T.; S. R. C. Penteado; N. Caldato \& Reis Filho, W. 2007. Pineus boerneri (Hemiptera: Adelgidae) - pulgão-lanígero-do-pínus - praga introduzida em plantios de Pinus spp. no Brasil. Comunicado Técnico 190, Colombo, Embrapa Florestas, 6 p.

McClure, M. S. 1982. Distribution and damage of two Pineus species (Homoptera: Adelgidae) on red pine in New England. Annals of Entomological Society of America 75: 150-157.

McClure, M. S. 1989. Biology, population trends and damage of Pineus boerneri and P. coloradensis (Homoptera: Adelgidae) on red pine. Environmental Entomology 18: 1066-1073.

McClure, M. S. 1990. Cohabitation and host species effects on the population growth of Matsucoccus resinosa (Homoptera: Margarodidae) and Pineus boerneri (Homoptera: Adelgidae) on red pine. Environmental Entomology 19: 672-676.

Mills, N. J. 1990. Biological control of forest aphid pests in Africa. Bulletin of Entomological Research 80: 31-36.

Moreira, M. A. 2001. Fundamentos do sensoriamento remoto e metodologias de aplicação. São José dos Campos, INPE, 208 p.

Moran, N. A. 1992. The evolution of aphid life cycles. Annual Review of Entomology 37: 321-348.

Tanton, M. T. \& D. Alder. 1977. The distribution and possible effects of the woolly aphid Pineus (Homoptera: Adelgidae) on Pinus radiata D. Don growing in the Australian Capital Territory. Australian Forest Research 7: 253-263.

Yassen, M. \& M. A. Ghani. 1971. Descriptions and notes on the biology of four new species of Adelgidae from West Pakistan. Bulletin of Entomological Research 61: 191-205.

Zondag, R. 1977. Pineus laevis (Maskell) (Hemiptera: Aphidoidea: Adelgidae), pine twig chermes or pine woolly aphid. New Zealand Forest Service, Forest and Timber Insects in New Zealand 25, 4 p.

Received 23/7/2010; accepted 30/11/2011

Editor: Daniela Maeda Takiya 